\section{The Tuition Battle at Mexico's National University}

\section{Daniel C. Levy and Jorge Arenas}

Daniel Levy is professor of educational administration and policy studies, Latin American studies, and political science, University at Albany. Address: ED 321, University at Albany, SUNY, Albany, NY 1222. Fax: (518) 442-5084. E-mail: <d. levy@ albany.edu>. Jorge Arenas is a doctoral student in educational administration and policy studies at the University at Albany, SUNY, Albany, NY 12222; e-mail: <ga8233@cnsvax.albany.edu>.

$\mathrm{T}$ he battle now raging over tuition at Mexico's $\mathrm{Na}$ tional University (Universidad Nacional Autónoma de México-UNAM) echoes battles of yesteryear while also reflecting new realities of Mexico in both higher education and politics. On March 15th of this year, the University's council passed the General Bylaw on Payments, breaking a tradition of virtually no tuition for the institution's student body of roughly 300,000 (which includes those at the "preparatory" preuniversity level). By April, UNAM found itself paralyzed by a student strike, and some "solidarity" strikes had spread to other institutions. For weeks, the strike and related issues have been front-page news in Mexico.

In one sense, this may appear to be much ado about next to nothing. The tuition proposal passed-less than the amount requested by the rector-is for just U.S.\$68 per semester, $\$ 51$ for the preuniversity level. This is roughly 30 percent of what public university students already pay in states such as Durango and Nuevo León. It is but 1 to 5 percent of what counterparts pay at private universities and indeed less than 10 percent of what many UNAM students were charged at their private secondary schools. Most UNAM students can easily afford the tuition. Moreover, the new bylaw is so lax that any student may obtain an exemption simply by claiming his or her family's income is too low; the penalty for providing false information is merely that the student loses the exemption. Nor would the tuition make much difference in an institutional budget twice that of the Ministry of Gobernación (interior ministry, with a portfolio including most political issues) and even more than twice that of each of the nation's 31 states.

But much is at stake. Perhaps Latin America's bestknown university, UNAM, has become a key battleground in a broader Latin American and, indeed, worldwide fight over tuition. Though other Mexican public universitiesall state universities and the Autonomous Metropolitan University, which joins the UNAM in the Federal District-have imposed tuition in recent years, UNAM occupies a singular place in the nation's political and social life. Here, tuition has been beaten back on several historical occasions-with some rectors leading the fight against government trial balloons and others proposing tuition-and losing their jobs in the ensuing protest.

The main economic and equity arguments are the familiar ones of who pays and who benefits. Tuition advocates highlight the inequity of tax money from all social classes paying for a higher education that goes overwhelmingly to middle class - which is to say, relatively privileged—students. The proposal is: let those who can afford tuition pay, while the rest are exempted. Supporters also highlight the private rates of return to a university education. Critics, on their part, fear that tuition will rise once the taboo is broken. Some argue that any tuition would place an intolerable burden on students of modest means and therefore reduce access.

However, it is the political arguments and ramifications that are most interesting in the UNAM case. Critics are fighting not just a modest tuition but what they see as an extension of a neoliberal agenda, World Bank promoted, into the heart of Mexico's cultural heritage. Many claim that tuition will bring the "privatization" of UNAM, elevating the power of the market and notions of efficiency over academic considerations and state responsibility. In turn, their antagonists denounce an absurd populism, one that masks self-interest in flowery, antiquated revolutionary rhetoric. One side points to Article 3 of the Constitution and its provision for free education, while the other says the article does not apply to higher education and that the same Constitution gives the university the right to set its own charges. Protesters say tuition is a poor substitute for, and a lame diversion from, the major issue of inappropriate limits on government funding, and the student movement calls for higher education to receive a huge increase in its share of the GDP, to 7 percent. Proponents of tuition say government lacks the full responsibility or ability to fund UNAM, so that quality depends on generation of alternative funds.

\section{Perhaps Latin America's best-known university, UNAM, has become a key battleground in a broader Latin Ameri- can and, indeed, worldwide fight over tuition.}

When UNAM student protesters included national democratization on their agenda in 1968 they met with a violent response from government; they were challenging an authoritarian, if usually comparatively mild, political system. Today, in contrast, Mexico is undergoing signifi- 
cant democratization, and virtually all political groups march under the democratic banner. In this case, however, one side - the opponents of tuition-makes democracy central to its case. Proponents of tuition concentrate on other rationales, though they argue that their proposal will contribute to a new accountability to the general public and to the strengthening of social institutions and civil society, as well as lessening the University's total dependence on the state.

\section{The main economic and equity argu- ments are the familiar ones of who pays and who benefits.}

The Democratic Student Coalition has denounced the tuition effort as authoritarian and attacked the approval process as lacking in transparency-pointing to the fact that the University Council met off campus for the first time ever. Of the 35 members not present, 28 were student representatives. Furthermore, the Coalition sees the Council vote as illegitimate because 70 percent of Council members are not elected but rather appointed by the University's governing board. The University administration counters that there was adequate notification since most members did attend. Additionally, the democratic nature of the bylaw is substantiated by the fact that it was approved overwhelmingly by those present; though figures vary, it appears that supporters would have had a clear majority even had all members been present. The positive vote included not just representatives from fields such as accounting but from the humanities and social sciences as well.

Nevertheless, the Coalition has demanded that the bylaw be revoked, the rector resign, and public discussions be held, followed by a plebiscite. The rector is amenable only to meeting with the Coalition. A faculty group has offered to mediate, so far without success. If the rector's off-campus strategy was intended to expedite the process and avoid a major political confrontation, he might well have been thinking about the failure of a predecessor, a decade earlier, who had attempted to promote tuition and other reforms by launching a major position paper and open university-wide dialogue. In any event, even many who think tuition is warranted believe the March political strategy has backfired, perhaps jeopardizing certain other reforms of the last decade.

Once again, as a decade earlier, a rector's initiative has pumped life back into student activism, which had been moribund by comparison with prior periods. Students re- tain the power to disrupt and to block or at least slow down certain reforms. Now, however, UNAM's political fight is playing out against a fresh background of national politics. In the past, the key external actor was the government and its official governing party; weighing reforms it might like against the cost in middle-class support and legitimacy, the government calculated whether to back reforms, stand on the sidelines, or even let the rector's head fall. Today, the executive branch is just one among many actors, and it is under attack, on the defensive, and vulnerable to a growing popular perception that things are out of control. The minister of education confines himself to lame statements about how UNAM will not be privatized. The quintessentially political Ministry of Gobernación is seen as further weakened by the disorder, its minister's presidential aspirations hurt. The governing party of the nation is in fierce competition with the party on the leftwhich holds the mayoralty of Mexico City - and another on the right. Congress, once an insignificant player is the forum for prolonged, impassioned debates on tuition. The rightist party is predictably mostly pro-tuition-as is the official party-but displays some internal differences and much reticence in the handling of a sensitive political issue in an era in which elective office must now be earned through appeals to the electorate. The left has staked out the strongest party position, obviously anti-tuition. Outside the Congress the rebel zapatistas and their charismatic leader, Subcommander Marcos, have seized the chance to broadcast their "antiauthoritarian" position against tuition.

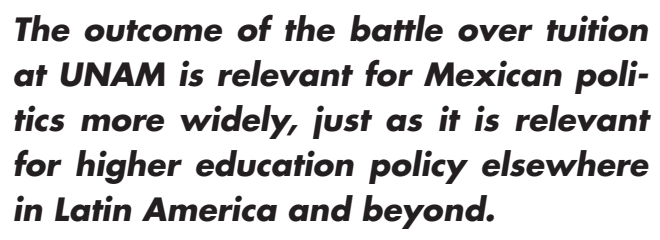

The outcome of the battle over tuition at UNAM is relevant for Mexican politics more widely, just as it is relevant for higher education policy elsewhere in Latin America and beyond.

Tuition thus takes its place alongside other political issues that are being keenly debated in a fractured, uncertain, changing, and democratizing Mexico. The outcome of the battle over tuition at UNAM is relevant for Mexican politics more widely, just as it is relevant for higher education policy elsewhere in Latin America and beyond.

Author's Note: After this article was written, the university administration capitulated to student demands by making new tuition voluntary and granting amnesty to protesters. However, the strike dragged on as student radicals tried to press their advantage. 